\title{
The Gravity of China's African Export Promise
}

\author{
Lauren A. Johnston(1), Stephen L. Morgan(2), Yuesheng Wang(3)
}

\begin{abstract}
Africa's largest trade partner, China, criticised for exchanging resources for manufactures, has promised to increase imports and optimise the structure of trade with Africa. Using a gravity model of China's imports for the years 19952009, we explore potential dynamics for this promise, uniquely accounting for market economy recognition and Taiwan recognition. The former is associated with increased imports, while the latter effect is ambiguous and statistically insignificant. Comparison of projected against actual imports across three growth-path-aligned economic geography typologies - resource-rich; landlocked and resource-poor; coastal and resource-poor - sets out China's imports trends in an abstract framework of African export potential. We find not only 'under' importing across a majority of resource-poor countries. We also find that current trade policy is the least applicable to these comparatively poor exporters' trade with China. If the latter are to serve a broader catalytic role in Africa's regional industrial transformation as compared to the role of coastal and resource poor countries in regional economic transformation in Asia and Latin America, China-Africa trade and investment policies may need additional thinking.
\end{abstract}

KEYWORDS: China, Africa, Trade, Gravity Model

Author details:

1. Lauren A. Johnston, PhD Graduate, School of Economics, Peking University, lauren.al.johnston@gmail.com

2. Stephen L. Morgan, Dean of Social Sciences, the University of Nottingham Ningbo China; Professor of Chinese Economic History, School of Contemporary Chinese Studies, the University of Nottingham; and Honorary Fellow, the School of Historical and Philosophical Studies, University of Melbourne.

3. Yuesheng Wang, Professor and Director, Department International Economics, School of Economics, Peking University

\section{Acknowledgements}

This research was undertaken with financial support from the China Scholarship Council and the World Bank. The authors thank James Adams, Chris Parsons, Zhifeng Yin and Hu Bo for their research support and comments. 


\section{Introduction}

In 2009 China became Africa's largest trade partner, a symbolic turning point in extra-regional economic relations after centuries of colonial-centric ties. Bilaterally China is now the largest export destination of South Africa, sub-Saharan Africa's (SSA) largest economy, and also of Angola, Benin, Congo (Democratic Republic), Mauritania, Sudan and Zambia, among others (IMF, 2010). This growing ChinaAfrica trade relationship is the culmination of changes that gained momentum in the mid-1990s. Our gravity model analysis of China's imports from Africa between 1995 and 2009 explores the potential for trade to generate positive development opportunities for Africa.

The visit of then Chinese President Jiang Zemin to six African nations in 1996 marked the shift in focus of China's relationship with Africa away from politics toward economics (Alden, 2007: 15). Change in both China and Africa motivated the shift. In 1991, China became a net oil importer, and rapid domestic growth prompted China to look for security of energy and other raw material supplies. Africa was seen as potential source of still undeveloped resources. In Africa, domestic economic and political change was afoot too. Apartheid came to an end in South Africa in 1994, while the economies of most of SSA began to perform better after 1995 (Arbache and Page, 2007a). In the preceding 20 years nearly all countries south of the Sahara saw zero or negative economic growth per capita (Radelet, 2010:1).

Absolute trade volumes have risen more than 100-fold since 1990 (Brautigam, 2010:1), with a 10-fold increase since 2000. The importance of trade however differs markedly for China and African economies. The share of China in Africa's trade is now higher than for any region other than the share of China in Developing Asia's total trade (Arora and Vamvakidis, 2010), with China also the region's largest trade partner. China's trade with SSA however remains less than trade with Japan alone: 3.4 per cent of exports of $\$ 1.203$ trn and 4.3 per cent of imports of $\$ 1.00$ trn in 2009 (IMF, 2010).

These increases in trade volume and more market-driven ties between China and Africa are helping to correct undervaluation of Africa by investors (Wang, 2007). They are also helping to generate some of the world's fastest growth rates (The Economist, 2011). At the political level these relations are fostered through ministerial-level discussions with African counterparts at the China-instigated 
Forum on China and Africa Cooperation (FOCAC). The first meeting was held in late 2000 with the aim to provide a platform to advance economic ties. ${ }^{1}$

Growth of China-Africa trade is not without controversy. The composition of trade flows has raised concerns, including that the exchange of African raw materials for Chinese manufactures will hinder the industrialisation ambitions of African economies (Giovannetti and San Filippo, 2009; Kaplinsky and Morris, 2007). In 2006, former South African President Thabo Mbeki warned: "If Africa continues to just export raw materials to China while importing Chinese manufactured goods, the African continent could be condemned to underdevelopment" (The Namibian, 2007, accessed 05/10/11).

At the 2006 FOCAC meeting China doubled the number of items that could be imported duty-free from Africa's Least Developed Countries (LDCs) to 440. Eightyeight percent of products on the list have at some point been exported to China. The average margin of preference was a 10.4 percent tariff. The estimated overall economic benefit, using a simple 'implicit transfer' method, is $\$ 10 \mathrm{mn}$ per annum (Minson, 2008). Realising the trade benefits for such change is far from easy. There is uncertainty about which products are exempt; many of sub-Saharan Africa's more important products are excluded and China's phyto-sanitary requirements are also presenting a hurdle (Danchi, 2010).

China subsequently further opened its market to poorer African exporters, offering zero-tariff treatment for 95 percent of exports from LDCs. In 2010, a zero tariff applied to 60 percent of their exported commodities. Since preferences apply only to the poorest economies they however have the secondary effect of excluding countries such as Kenya and Ghana that are on the threshold of realising a manufacturing base (Venables, 2008: 14).

Similarly excluded from trade preferences is South Africa, which believing job losses were occurring in its textiles sector due to increasing Chinese imports, in 2007 imposed quotas on selected lines from China (van Eeden, 2009). Africa has struggled to deal with the challenge of China's trade competitiveness by 2011. South African President Zuma asked an audience in 2011: "How do we trade with China in a way that benefits us as well?" (Business Day, 2011). Addressing a seminar in South Africa to mark the $10^{\text {th }}$ anniversary of FOCAC, then Chinese Vice-

\footnotetext{
${ }^{1}$ The Forum includes countries from not just south of the Sahara that are the focus of this study, but excludes countries not observing the One China policy, Swaziland, Burkina Faso, the Gambia and Sao and Tome Principe, which do not have diplomatic ties with China.
} 
President Xi Jinping committed China to "enlarge the scale of China-Africa trade, and optimise the trade structure". He promised that China would seek opportunities to increase its imports. ${ }^{2}$ China's 2010 inaugural white paper on economic ties between China and Africa, China-Africa Economic and Trade Cooperation (PRC State Council, 2010), recognised the need to optimise the level and composition of trade.

Multiple factors influence the notion of 'optimal' trade, both by level and composition. In the field of economic geography trade levels and prospects have been linked to endowment level and geographic position. Empirically, 'over' and 'under' trading have been estimated using gravity models. First applied empirically to international economics by Tinbergen (1962) and Pöyhönen (1963), the gravity model links trade levels to 'distance' (costs of trade) and 'mass' (GDP, population, and so on). Theoretical foundations have since been established (Anderson, 1979; Bergstrand, 1985, 1989; Helpman and Krugman, 1985; Deardorff (1998).

Here we use a gravity model to scope China's promise to increase the level of trade, in this case implicitly and necessarily with reference to China's own international import norms. A global sample better estimates trade potential; it aligns China's trade promise to increase the level of imports toward African economic development, recognises the direction of trade flows, and finally avoids the effect that an Africa-only sample would largely reflect oil trade.

Variables such as common language and common colony are typically included in gravity models, but these are less applicable to China. Instead our gravity model is uniquely augmented to include a 'huaqiao' (overseas China) variable capturing high densities of Chinese outside China proper in Taiwan, Hong Kong and Singapore, alongside variables for the recognition of China as a market economy, and the recognition of Taiwan. We also remove the East Asian island economies that play a leading role in China's re-export chain from our island dummy variable, ensuring the sign presumably is negative for our 'under' and 'over' estimations of African exports to China.

Our results are interpreted to recognise the developmental hurdle that is Africa's uniquely complex economic geography. Africa has "a massive land area divided

\footnotetext{
${ }^{2}$ At the China and Southern African Development Community (SADC) Business Forum in June 2011, Chinese Vice-Premier Wang Qishan said China will increase imports from member states of the SADC to strengthen mutually-beneficial trade. (Trade Africa blog, http://www.tradeafricablog.com/2011/06/china-to-increase-imports-from-sadc.html).
} 
into 44 countries, with overall a low population density compared with other lowincome regions" (Collier, 2008:3). By the 1990s, only 35 percent of Africa's population was living in coastal, resource-scarce economies compared with 88 percent for the rest of the developing world, while resource rich economies accounted for 30 percent of populations in Africa compared with only 11 percent elsewhere (Collier and O'Connell, 2007:2). The most striking difference between Africa and other developing regions lies in the proportion of the population living in landlocked and resource-scarce countries - this proportion was about 30 percent of Africa's population, against 1 percent elsewhere (Collier, 2008: 5).

As a result, compared with Asia and Latin America over the last half-century where coastal and resource-poor economies had led regional industrialization transitions, in sub-Saharan Africa these countries have performed poorly (Growth Report, 2008). This trait is compared both to countries of the same grouping elsewhere and also relative to resource-rich and landlocked sub-Saharan African countries against the relevant international benchmark.

Our economic modeling and economic geography analysis serve both to give quantitative scope to China's promise to increase its imports from Africa, and to better understand the longer-term dynamism of recent trends in China's trade with Africa. Our framework enhances the analysis of contemporary Chinese trade patterns while also identifying the potential for African development.

\section{INSERT TABLE 1 ABOUT HERE}

Table 1 groups sub-Saharan Africa countries into three economic geography typologies. Observers of China's rising oil imports from Africa may be surprised by the classification of former Sudan as resource-poor. Resource rich economies are defined as those generating more than 10 percent of GDP from primary commodity rents, thus reflecting the productive value of each country's relative land abundance. Our classification follows Collier and O'Connell (2007), who used a 10 percent threshold because price volatility may lead some economies to flip backwards and forwards across this threshold year-to-year for their sample period of $1960-2000 .^{3}$ No matter the classification of Sudan and Congo DRC, our results highlight the scale of the 'under' importing from non-resource rich Africa. More worryingly is that China and Africa have no policies in place to assist directly coastal and resource-poor Africa, despite their recognised development needs.

\footnotetext{
${ }^{3}$ The classification is complicated by the fact that exploitation of land is endogenous to GDP itself, as well by the opportunities of non-land GDP.
} 
The rest of this paper is structured as follows: the second section outlines relevant previous research; the third section presents the stylistic facts defining contemporary China-Africa trade and some of the policy variables affecting that relationship; the forth section explains the gravity model and discusses some recent relevant gravity papers; the fifth section describes the data sources and the estimation technique used for the gravity model in the present paper, while the sixth section presents our results; the seventh section discusses the implications and limitations of the results, and the eighth section concludes.

\section{China-Africa Trade: Previous Research}

China-Africa trade-related research has distinguished the direct from indirect effects of China on African economies. Effects may also be complementary or competitive. Jenkins and Edwards (2005) summarise the effects of Asian drivers, China and India, on African economies in Table 2.

\section{INSERT TABLE 2 ABOUT HERE}

An example of an indirect effect is that China is driving up demand for resources, while its manufactured exports push down prices for would-be competitors (Kaplinsky, 2005). Resource rich countries, including Angola, Congo DRC, Guinea and Mauritania are winners (Stevens and Kennan, 2005). Mauritius and Madagascar in contrast have suffered adverse shifts in both import and export prices (Zafar, 2007). An additional indirect effect related to China's demand for some of Africa's resources are the effects described as Dutch disease, the displacement of manufacturing and agricultural activity by resource extraction. Bova (2008) estimated 2,000 jobs were lost in Zambia's horticulture sector owing to Dutch Disease. The country's largest textile mill - built with Chinese aid in the 1970s - was reputedly closed down due to clothing imports from China (Kaplinsky and Morris, 2007).

Giovannetti and Sanfilippo (2009) used gravity modelling to study direct and competitive displacement effects of China's trade on African trade. The displacement effect was significant for textiles, clothing and footwear, with more limited impact on light manufactures that used medium-level technology. The absence of regional production networks in Africa, they believe, makes a 
replication of East Asia's 'flying geese ${ }^{4}$ success more difficult. Like Chen et al (2006) and Venables (2008), they found that third market trade preferences, in the traditional markets of the US and Europe, were important for preserving African market access in the face of the competitiveness of third party exporters.

Brautigam (2010) argues China has recognised the role of trade and leveraging dynamic comparative advantage in its own development could provide lessons for Africa along lines of 'flying geese' industrialisation. Where Giovannetti and Sanfillippo (2009) undertake an aggregated cross-country study, Brautiguam's cites country-level cases of spillovers through partnerships with Chinese firms, within the textiles industry. Broadman (2007) used a gravity model to explore China-Africa FDI flows, finding investment from China into Africa complements rather than substitutes for bilateral export flow.

Although such papers reveal the longer-term picture may be brighter than current trends suggest, cross-country conclusions are inconsistent. For example, fears that the competitive effects of China's manufacturing exports are swamping African economies as a whole are unsupported empirically. Exaggeration of such effects, Shafaeddin (2004) argues, stem from underestimation of China's own declining cost advantages, and also estimation difficulties arising from the difference in structure of labour-intensive production in China and other countries. Similarly, calculations of the rank correlation of China's exports against those of other developing country exporters, often reach contradictory conclusions. For example, only half of such country-level results of Jenkins and Edwards (2006) agree with those of Stevens and Kennan's (2005).

\section{China-Africa Trade: Stylistic Facts and Polices}

\subsection{Stylistic facts}

The Heckschler-Ohlin ( $\mathrm{HO}$ ) trade model emphasises the role of dynamic factor endowments as the main driver of trade, rather than the static comparative

\footnotetext{
${ }^{4}$ Akamatsu $(1961,1962)$ proposeda multi-tiered hierarchical 'flying geese' model to explain the sequencing of East Asia's industrial development. The model describes how industrialization spreads from developed to developing countries: the initial 'goose' (the frontier economy) leads the second tier 'geese' (developing economies) and these in turn are followed by third-tier geese (least developed economies) through a process of gradual outsourcing. An alternative version of the model is the Vernon product cycle model.
} 
advantage model of Ricardo. Under $\mathrm{HO}$ assumptions, countries will export the good that uses intensively the factor with which it is most abundantly and cheaply endowed and import products that use scarce factors (WTO, 2008: 32). China reflects well these predictions, exporting labour-intensive manufactures and importing raw material resources.

\section{INSERT TABLE 3 about here}

The aggregate level of trade between China and Africa has risen significantly in recent years. African trade dependencies have also risen (Table 3), highlighting the relative growth of trade with China. Export dependency is the ratio of bilateral exports sold to one country to total exports. Among the 10 countries in Africa with the highest export dependencies with China as listed in Table 3, six are resource rich - Mauritania, Angola, Congo Rep., Zambia, Gabon and Equatorial Guinea. Only Equatorial Guinea among them has lower export dependency with China than it did in 1990. Countries with low export dependencies with China include Comoros, Seychelles, Niger, Sao Tome and Principe, Somalia and Liberia. Among those with the highest import dependencies, Sudan, Nigeria and Benin were in the same list in 1990. Angola, Congo Republic and Equatorial Guinea rank in the top 10 for each of import and export dependency.

Discrepancies in reported bilateral trade data complicate analysis of the trade balance. Chinese data show an aggregate surplus to Africa of US\$720.8mn in 2009, while African data reported to the IMF (2010) shows a deficit of US\$10.1b. No matter the data used, oil-exporter Angola's surplus stands out - it accounts for more than half of the sub-region's surplus with China. In 2009, according to African data, nine SSA economies ran a trade surplus with China: Angola, Sudan, South Africa, Zambia, Equatorial Guinea, Mauritania, Gabon, Burkina Faso and Central African Republic (IMF, 2010). Chinese data also reports a surplus for Cameroon and Zimbabwe. Apart from the cotton exporters Burkina Faso and Central African Republic, those with a surplus exports of fuels and minerals.

INSERT TABLE 4 about here: Composition of China's imports and exports

Table 4 decomposes China's trade by commodity grouping, allowing comparison between China's trade with Africa and its trade with the world. The composition of China's exports to Africa is roughly consistent with its exports to the world, while imports rather reflect HO-predicted endowment complementarities, with fuels and mining imports from Africa greater than China's global average. Manufactured 
imports from Africa comprise only 6.02 percent of China's imports, compared with 67.14 percent from the rest of the world, and 0.39 percent of China's total manufacturing imports. For comparison it is noted that oil as a percentage of US imports from Africa peaked at 63\% in 2008 (Standard Bank, 2011). China's 2010 whitepaper on economic ties with Africa notes there has been an increase in exports of light manufacturers from Africa to China in recent years, and re-iterates China's commitment to enhance such imports (PRC State Council, 2010: 3).

\subsection{Policies}

The absence of diplomatic relations between two countries may be expected to increase the formal costs of trade. For the PRC, the first 30 years after 1949 was a period of relative economic autarky during which international relations and trade were shaped in part by timing of diplomatic recognition. Trade and aid throughout this period served as tools of Beijing's foreign policy goal to establish its claim as the legitimate government of China in place of the Kuomintang regime on Taiwan. Among the first countries to recognise Beijing were Guinea and Sudan in 1959, followed by Ghana (1960), Congo DRC (1961), Kenya (1963), and Benin and Congo Republic (1964). The year of recognition also depended on when the particular African state became independent too.

Several countries have switched diplomatic ties, several times, over the decades. Only Swaziland, a member of the Southern Africa Customs Union, has consistently recognised Taipei. Such shifts in recognition annul previous bilateral Foreign Affairs or Ministry of Commerce representations. We hypothesize that a shift to Taipei will increases trade policy distance with China, and adversely affects trade flows, while recognition of Beijing will shorten effective distance. ${ }^{5}$

Following Rose (2004), we assume China's 2001 accession to the WTO will not directly or significantly affect trade flows between China and WTO members compared with non-members. China's WTO accession agreement brought together more than a dozen bilateral trade agreements from the late 1990s, including multilateralisation of a 1999 US-China bilateral agreement to designate China a market economy from 2015.

Market economy status is important when firms from non-market economies are accused of dumping goods in a market economy, in which case they can be

\footnotetext{
${ }^{5}$ At present, among Sub-Saharan African countries, The Gambia, Swaziland, Lesotho and Burkina Faso maintain relations with Taipei.
} 
challenged within the local trade jurisdiction of the market economy (Green, 2004). Goods identified as selling at 'less than fair value' can be claimed to cause 'material injury' to the industry of the complainant market economy and thus lead to the imposition of counter-veiling duties (Panitchpakdi and Clifford, 2002:196). Since the burden to disprove a dumping allegation falls on the non-market economy, political and bureaucratic whims may put at risk the business of exporters from non-market designated economies. ${ }^{6}$ We assume recognition of China as a market economy to be positively associated with bilateral trade flows.

There is an inherent risk here that early recognition of China as a market economy is more likely from trade complementary countries. For Africa the pattern is inconsistent: among so-classified resource-rich countries, Angola had not recognised China within our survey timeframe though Nigeria had; among coastal and resource-poor East Africa, Tanzania had not, but Kenya had. That our variable is time-variant also allows the capture of potential related trade variation within and between groups across time, such that a potential for face-giving first-mover advantage is implicitly tested.

In the absence of an official public list of countries that have granted China market economy status ahead of the WTO timeframe, we compiled a list from several sources, including the Ministry of Commerce's website, reciprocal African government websites and WTO sources, double checking against local newspapers. For end-2009 we identified 14 countries that have recognised China as a market economy: Nigeria, South Africa and Togo (2003); Central African Republic, Gabon, Kenya, Liberia, Mali, Mauritania, Niger, Sierra Leone, Sudan and Zambia (2005), and Guinea (2006).

Aside from market economy status, other variables could also be included in our framework. China has signed several FTAs in recent years with several different countries or regions, including Chile (2006), Pakistan (2006), New Zealand (2008), Singapore (2008), Peru (2009), and the Association of South East Asian Nations (2010). Both recent and small compared to the scale of China's overall trade, these did not demonstrate an impact on China's import levels within in our gravity modeling.

China has also fostered the establishment of Special Economic Zones (SEZ) in four countries in Africa - Ethiopia, Mauritius, Nigeria (two) and Zambia. Drawing on the

\footnotetext{
${ }^{6} \mathrm{~A}$ prosecuting country could for example use third country costs as a guide to the costs to make a product in the non-market economy.
} 
Chinese experience of SEZs, these seek to increase the value-added of exports and to promote industrial clustering. Early research questions if these African zones can emulate China's success (Brautigam et al, 2010; Brautigam, 2011). Our modeling found no significant relationship between presence of an SEZ and exports to China, at this stage.

\section{Model, Estimation and Results}

\subsection{The Model}

Gravity modelling has been applied extensively to research exploring China's trade. Benassy-Quere and Lahreche-Revil (2003) examined the effect of revaluation of the Chinese currency, the yuan, on China's trade. Eichengreen, Rhee and Tong (2004) explored the crowding out effects of China's exports on Asian economies, finding that the greatest effect was for consumer goods. Greenaway, Mahabir and Milner (2006) found similarly that China displaced greatest the exports of the more advanced Asian exporters, an effect which has increased with time. Batra (2004) found China to be 'under-trading' with India, since which time China has become India's largest trading partner.

Gravity modelling has also been used to explore "natural" levels of China's bilateral trade, imports and exports. Bussiere and Schnatz (2006) found that for China's size and location it is already well integrated into the world economy. Edmonds, La Croix and Li (2008) found China had excessive orientation toward foreign trade, though this varied between trade partners. They highlighted that China's trade with Angola, Sudan and Zimbabwe was higher than expected. For this study we focus explicitly on China's imports, and apply the following model:

$$
\begin{array}{r}
M_{i j t}=\beta_{1}+\beta_{2} \ln G D P_{j, t-1}+\beta_{3} \operatorname{lncGDP}_{i(t-1)}+\beta_{4} \text { lndist }_{i j}+\beta_{5} \text { lnpop }_{j t}+\beta_{6} \operatorname{lncpop}_{i t}+\beta_{7} \operatorname{lnexc}_{i j t} \\
+\beta_{8} \text { landlk }_{j}+\beta_{9} \text { islandsall }_{j}+\beta_{10} \text { contig }_{i j}+\beta_{11} \text { huaqiao }_{j}+Z_{i j t}^{m}+u_{i j t}
\end{array}
$$

Where:

$M_{i j t}=$ Data on imports reported by China from IMF, Direction of Trade Statistics. $G D P_{i j t}=$ GDP in current prices from the World Bank, where ' $c$ ' as a prefix reflects China, World Bank, World Development Indicators.

dist $_{i j}=$ Greater circle distance between capital cities, taken from the gravity database of the Centre d'Etudes Prospectives et d'Informations Internationales (CEPII).

pop $_{i j t}=$ Population of China \& exporting countries, where ' $c$ ' as a prefix reflects China, World Bank, World Development Indicators. 
exc $c_{i j t}=$ Units of real local current per RMB, IMF, calculated using International Financial Statistics.

Iand $_{i}$ : Dummy variable reflecting whether China and trade partner country $j$ share a boundary; source: CEPII.

contigij: A dummy variable equal to 1 where country $i$, China and a given trade partner, share a common border; source: CEPII.

islandsall $l_{j}$ : A dummy variable equal to 1 where country $j$ is an island; source: CEPII.

huaqiao $_{j}=$ A dummy variable equal to 1 for countries/territories where a language of China or a similar dialect is spoken: Hong Kong, Taiwan and Singapore.

$Z^{m}{ }_{i j t}=A$ vector of additional policy augmentations uniquely associated with trade with China as outlined.

Following gravity theory, distance is expected to be negatively associated with trade flows, and positively related to import partner income. Since our model explores the dynamics of China's imports from the world, we expect that appreciation in China's exchange rate in relation to each trade partner will be positively associated with imports from that country.

China is distinctive in terms of the geography variables of the gravity model. Contiguity is generally positively associated with trade flows and roughly of the order of about 0.5. For China, however, we expect a negative sign because of the distance between contiguous countries that mostly border the inland western provinces. China's centers of economic activity are in contrast clustered along its eastern coastline. Similarly, instead of a negative coefficient that is typically attached to the island dummy, we expect the island dummy to be positively associated with trade flows because China's trade is large with advanced proximate island economies, such as Japan and Taiwan. Only for the landlockedness of trade partners do we expect to the usual negative sign. We furthermore account for the 'common language' element of trade with Singapore, Taiwan and Hong Kong with a 'huaqiao' (overseas China) dummy variable.

Given the distinctive differences in the economic geography, and our interest in applying the results to explore China's import dynamics and potential with Africa, we augment our model as follows:

- Island $i j$ : a dummy variable equal to one for island economies, excluding proximate trade partner island economies, including Japan and Taiwan. 
- Huaqiao $i j$ : a dummy equal to 1 for Taiwan, Hong Kong and Singapore to account for shared culture between China and these economies.

We expect the adjusted island dummy to shift from positive to negative accordingly, a result that reflects China's trade with island economies elsewhere. We expect a positive association between the high presence of overseas Chinese and trade.

China has put in place several distinctive institutional arrangements that potentially impact trade. These include recognition of the One China policy and more recently whether a trade partner has recognised China as a market economy. Past studies have not sought to take account of these arrangements in modeling China's trade. We have augmented the model to include these variables. We expect the failure to recognise the One China policy will add 'distance' between economies and thus reduce trade, since this disallows bilateral diplomatic representation. In contrast, recognition of market economy status ahead of the 2015 deadline agreed among WTO member countries should signal closer working trade relations and be positively associated with trade. From (1), our $Z$ vector is comprised of the following:

- OneChina ${ }_{i j t}$ : a dummy equal to 1 for the years that a country did not observed the One China Policy; source: Ministry of Foreign Affairs, Taiwan.

- Market ${ }_{i j t}$ : a dummy equal to 1 for the years that a country has given China market economy status; source: Ministry of Commerce of China, and trade partner trade ministries.

Our final augmented model thus is:

$$
\begin{aligned}
M_{i j t}=\beta_{1}+\beta_{2} \operatorname{lnGDP}_{j,(t-1)}+\beta_{3} \operatorname{lncGDP}_{i(t-1)}+\beta_{4} \text { lndist }_{i j}+\beta_{5} \text { lnpop }_{j t}+\beta_{6} \text { lncpop }_{i t}+\beta_{7} \text { lnexc }_{i j t} \\
+\beta_{8} \text { landlk }_{j}+\beta_{9} \text { island }_{j}+\beta_{10} \text { contig }_{i j}+\beta_{11} \text { huaqiao }_{j}+\beta_{12} \text { OneChina }_{i t} \\
+\beta_{11} \text { market }_{i j t}+u_{i j t}
\end{aligned}
$$

\subsection{Estimation}

Our sample comprises data covering 1995-2009 for 155 countries, allowing the results to reflect a broader internationalised concept of trade potential in terms of exports to China. A sample comprised only of Africa would less effectively capture import potential and be biased by the dominance of oil and minerals exports of present imports from Africa by China. The Democratic Republic of Korea and Myanmar, two contiguous countries with close ties to China, were excluded because of inadequate data, as was the Chinese Special Administrative region of 
Macao. Similarly, Djibouti, Sao Tome and Principe, Somalia and Zimbabwe were also dropped. The lack of disaggregated trade data for members of the Southern Africa Customs Union led to exclusion of Swaziland, Lesotho, Namibia and Botswana, which bias results for the One China policy variable since Swaziland is a long-term supporter of Taiwan. We used trade data from the IMF Direction of Trade Statistics database. The data for our independent variables was mainly from the World Bank World Development Indicators database, supplemented with data from the CEPII gravity dataset.

Empirically, heteroskedasticity and the presence of zero trade flows influence the estimation of gravity models. Heteroskedasticity is encountered because the income elasticity of trade is different at different income levels and between goods; at higher income levels trade-related infrastructure and administration is more efficient; and data quality itself is correlated with national wealth. The error term of a gravity model is thus frequently non-homoskedastic, which result in estimates that are inefficient, even if unbiased.

Zero trade flows are also an issue since unlike gravity trade flows can be zero. The scale of China's trade expansion has reduced the frequency of zero bilateral trade flows over time. Some remain, including the small island economies, such as Cape Verde. Depending on the origin of a recorded zero trade flow, the result will be to produce biased or inconsistent coefficient estimators (Martin and Herath, 2008).

Further, since ordinary least squares (OLS) and Poisson estimation techniques require a log-linearised dependent variable, the researcher confronts the problem of non-integer values. Practically, it is common to either drop zero values altogether or to add 1 to all values. Hurd (1979) illustrated that in a truncated sample heteroskeadisticity can produce large sample biases. Adding 1 reduces the consistency of estimators.

Our benchmark results are derived using the Pseudo-Poisson Maximum Likelihood (PPML) method, which Silva and Tenereyo (2005) proposed for its strengths in addressing heteroskedasticity and for providing a natural way of dealing with a zero dependent variable. Unlike a standard Poisson or OLS regression, the PPML dependent variable need not be in the logarithmic form. The PPML does not require data to follow a Poisson distribution, but only that the conditional mean of the variable of interest is correctly specified (Silva and Tenereyo, 2005). PPML coefficients are typically lower than those of other techniques, including OLS. 
Following Baldwin and Taglioni (2006), we include time dummies to capture price effects across trade partners that cannot otherwise be consistently de-based. The same paper also suggests time dummies to eliminate the effects of omitting the term than Anderson and van Wincoop (2003) labeled multilateral resistance. Relative price shifts between China and a trade partner are also accounted for through use of a real exchange rate variable. We finally reduce potential endogeneity issues between trade levels and GDP by using lagged rather than current GDP.

\subsection{Results}

A summary of our PPML results for the augmented model is presented in Table 5. These results broadly confirm our hypotheses. They show:

- Partner GDP is positively associated with China's import levels but less than in a typical gravity result; the effect of China's GDP is negative and less significant;

- The real exchange rate (RMB per unit of foreign currency) between China and a trade partner has a limited and insignificant effect on China's imports;

- Distance reduces import levels;

- Demand for imports on average rise with trade partner population, while the result for China's population is only significant at the 10 percent significance level;

- Landlockedness is negatively associated with exports to China;

- China has an atypical tendency to trade with island economies and also inversely so in trade with contiguous neighbours;

- China trades more highly with those sharing similar linguistic orientation.

For our newly explored institutional variables:

- Recognition of market economy status, ceteris paribus, is associated with increased trade flows;

- The effect of non-recognition of the One China policy appears to have a negative effect on trade but this effect is not further explored herein.

INSERT TABLE 5 OLS and PPML benchmark results ABOUT HERE

These findings tell us that China's trade broadly agrees with the predicted trends in standard gravity model: trade rises with partner GDP, partner population, and common linguistic roots. Trade falls with distance. While trade typically falls with 
island status and rises with a contiguous border, contrarily for China the opposite holds, highlighting the country's unique 'gravity' in international trade. The clustering of China's population and economic activity on the eastern coastline, the proximity of that coastline to a number of significant island economies and the relatively small economic size of most of the neighbouring contiguous economies combined with their distance from the developed eastern provinces explains these contrary findings.

Steps taken to reduce policy distance, in our study proxied through recognition of China as a market economy are associated with an increase in imports. Greater institutional policy distance - the non-recognition of the One China policy - is significantly associated with imports by China, but the results are inconsistent between estimation methodologies. The effect is large and positive under OLS, but relatively small and negative using PPML.

\subsection{Sensitivity Checks}

We perform three sensitivity checks. Firstly we adjust the island dummy to examine if the result defaults to the more usual negative coefficient estimate when the East Asian re-exporting island economies are excluded. Secondly, we explore the China-Africa import effect through use of a dummy variable SSA. Finally, we use three separate dummies to explore the effects of the different economic geographies.

For our island sensitivity check we remove proximate important Chinese trade partner island economies including Japan and Taiwan from the island classification. The re-run of (2) as expected reverses the sign of earlier coefficient estimate ($0.516, p=0.000$ ), a result consistent with most gravity model findings. Given our interest in trade level projections for countries including Africa's island economies, we adopted this adjustment for all onward estimations.

Re-running newly adjusted equation 2 inclusive of a dummy variable for SSA countries produced a negative but insignificant 'SSA' effect $(-0.192, p=0.394)$. This was the first indication of our overall under-importing hypothesis. The result however was not consistent over time.

Time period effects within the sample period were tested through division of the sample into two sub-periods, 1995-2001 (t1) and 2002-2009 (t2). The timing pivots around China's WTO ascension in 2001 and the start of its 'Going Out' policy 
that encouraged Chinese firms to invest abroad. In the first period, the SSA dummy is negative and significant $(-0.994, p=0.00)$, while in the second period the dummy is positive but insignificant $(0.019,0.941)$. There has been a longstanding 'negative Africa dummy' attached to international growth regressions (Easterly and Levine, 1997). These results suggest that for China-Africa trade the sign of that dummy is changing, even if not yet statistically significantly.

Given signs of a changing 'Africa dummy' and the association of growth patterns across and between economic geography typologies we used dummies for each of the three typologies to explore the economic geography of China's imports from Africa. Using the entire sample period there is a positive effect for resource richcountries, but this is insignificant $(0.315, p=0.359)$. For landlocked and resourcepoor countries, the result is significant and negative $(-0.525, p=0.046)$, and more so for coastal and resource-poor countries $(-0.767, p=0.002)$.

Looking at these disaggregated effects across time, in t1 there is a near or above unity negative and significant effect across all typologies: resource-rich $(-0.805$, $\mathrm{p}=0.009)$; resource-poor and coastal $(-1.109, \mathrm{p}=0.000)$; resource-poor and landlocked $(-1.171, \mathrm{p}=0.018)$. In t2 the resource-rich dummy becomes positive but is insignificant $(0.599, p=0.107)$; is significant and less negative for resourcepoor coastal categories $(-0.625, p=0.024)$, and negative but insignificant for landlocked resource-poor countries $(-0.288, p=0.327)$. The results suggest that coastal-resource poor economies may have benefitted least from China's increased trade with Africa over the period 1995-2009.

\section{INSERT TABLE 6 ABOUT HERE:}

Results of analysis over the two mentioned time periods are presented in Table 6. Compared to the earlier results, the size of the coefficient attached to China's population is much larger in the second period, but significant only at the 10 percent level. The effect of real exchange rate on Chinese imports is relatively small, and sensitive to change across time. Similarly, the impact of China's GDP is inconsistent, changing in sign and significance.

In terms of our new institutional variables, there is no related time period effect for market economy status because recognition of China's market economy status applies only within $t 2$. The OneChina variable changes sign across the period, but is now and consistently insignificant, a change from the results presented in Table 5, and highlighting an opportunity for related and focused research. In light of 
these results, we adopt the full sample period estimation for our onward projections, as follows:

$M_{i j t}=22.78+0.46 \operatorname{lnGDP} P_{j, t-1}-2.21 \operatorname{lncGDP}_{i, t-1}-0.82$ lndist $_{i j}+0.40$ lnpop $_{j t}+0.14 \operatorname{lnexc}_{i j t}-$ 0.61 landl $_{j}+0.52$ island $_{j}-1.21$ contig $_{i j}+1.57$ huaqiao $_{j}+0.35$ market $_{i j t}$ (3)

\subsection{Over and Under Exporting}

Despite the gravity model being widely used to make trade projections, this was not its intended purpose. The following results are thus best understood as relative comparisons between and within typologies, rather than absolute measures of the appropriate level of trade.

Factors directly affecting the reliability of these estimates include that our sample relies on Chinese data alone, rather than data adjusted for bilateral discrepancies, which may bias the results. Our sample is global rather than specific to the case of Africa, and scale effects may upwardly bias estimates of 'over-trading', since the model assumes trade to be a linear function of GDP. But the global sample is preferred for two reasons: it better helps to understand Africa's trade and trade potential with China, and secondly it minimises the biases arising from the dominance of trade in oil within an African sample.

\section{INSERT TABLE 7 ABOUT HERE}

Table 7 shows the weighted under/over-trading ratio according to the three typologies adopted. The indirect and inverted lens of economic geography highlights the resources-bias of China's recent rising imports from Africa. The data shows China to have been on average 'under' importing from all typology groupings in 1995. By 2009, when China became Africa's largest trading partner it rather 'over' importing from all typologies, on average. When the big four trading partners, Angola, Congo DRC, South Africa and former Sudan are excluded however, China is on average significantly 'under' importing from all but the resource-rich group of countries. Specifically, China 'over' imports by a factor of almost five from the resource-rich typology, even after excluding the largest of those exporters, Angola. In contrast, China 'under' imports, by on average twothirds, with resource-poor economies, whether coastal or landlocked, and similarly excluding the outliers of the biggest regional traders with China. 


\section{5-1 Resource-Rich Economies}

Of the 14 countries that are classified as resource rich, Nigeria and Angola are among the larger economies. Three are also landlocked: Botswana, Swaziland and Zambia (Botswana and Swaziland are excluded for lack of data). None has an east-facing port. Over half are LDCs (Angola, Equatorial Guinea, Guinea, Liberia, Mauritania, Sierra Leone and Zambia), which qualify them for LDC-related Chinese trade preferences.

Eight of the 12 economies in our sample have given China market economy status over the sample period, the highest percentage of any typologies, while some of those that have not are members of a custom union. Swaziland, a member of South African Customs Union, also does not adhere to the One China policy. In general, this group has historically not had turbulent relations with China; they have also disproportionately been recipients of Chinese infrastructural lending. Angola, Sudan and Nigeria comprise three of the four largest recipients of China's SSA infrastructure lending, with recent financing to Sudan and Nigeria equal to $\$ 1.3 \mathrm{bn}$ and $\$ 5.4 \mathrm{bn}$ respectively (Foster et al, 2009). Loans to countries of this typology reflect their qualification for Angola lending terms, which directly links loans to the extraction of resources as collateral.

China's lowest density of 'under' exporting with economies in sub-Saharan Africa is with countries of the resource-rich typology. Within this category, countries 'over' exporting by a scalar of at least five are: Congo Republic, Zambia, Equatorial Guinea, Mauritania, Nigeria, Angola, and Gabon Only with the three members of West Africa's Mano River Union - Guinea, Liberia and Sierra Leone - was China still 'under'-importing by 2009 . This contrasts to 1995, when China was 'under'importing from every country in the grouping.

\section{INSERT FIGURE 1 ABOUT HERE}

The transformation of China's trade ties with resource-rich SSA, excluding outlier Angola, is demonstrated in Figure 1. China takes more than 30 percent of the exports of Congo Rep. and Mauritania, and more than 20 percent of Zambia's. Not all 'over' exporting is however associated with a country in Africa having a trade surplus: Nigeria 'over-exports' and yet has a large trade deficit with China. Among the over-exporting resource rich countries, Angola sends to China nearly half of its oil-based exports. 
China is on average over-importing from the resource-rich typology, with the exception of the Mano River Union countries. This group's Ionger-term developmental trajectory is different from the experience of recent high-growth stories in Asia and Latin America. As a result commodity cycles and governance issues, growth of exports alone in this group has not been so far associated with sustained growth and industrial transformation either within or between countries across time (Growth Report, 2008). Although the growth in trade is helping to transform parts of Africa, generating sustainable economic transformation is a challenge. The gravity of China's African trade promise with resource-rich countries may lie in not only continuing to grow the level of trade but in optimization of the structure of trade.

\section{5-2 Coastal and Resource-Poor}

Coastal resource-poor economies are more diversified than the other typologies. Ten of the 17 are LDCs, a smaller proportion than among other typologies. It includes the region's largest economy, South Africa, together with smaller economies such as The Gambia. The grouping also includes Africa's island economies, many of which export nothing to China.

Seven of the 17 by 2009 had granted market economy status, and two countries did not observe the One China policy. Mauritius is the only economy within this typology to play host to a Chinese-supported SEZ. Coastal and island economies, which have extensive tourism industries, are most likely to have received Approved Tourism Destination status for outbound Chinese tourists from the Chinese government. Within our sample period, these countries included South Africa (2003); Tanzania (2004); Mauritius (2004); Seychelles (2004); Kenya (2004); Cape Verde (2009) and Ghana (2009).

FIGURE 2: Over/Under Trading, Resource-Poor Coastal Economies

As Figure 2 illustrates, on average our model finds these countries to significantly 'under'-export to China. Over the sample period however the gap between actual and predicted export level has narrowed substantially. By 2009 three economies were 'over' exporting to China: South Africa, Tanzania and Mozambique. Benin's exports had also reached more than half the predicted level by 2009 . Recent trade between Mozambique and China has grown exceptionally fast, at an average rate of 30\% (AllAfrica, 2012). Benin's export levels may be over-estimated as a result of it serving as a port for some exports of the landlocked countries to its north. 
South Africa is an exception. As Africa's largest economy, China's largest trade partner in Africa, and with China as its largest trading partner, South Africa in contrast "over-exports" second only to Angola according to our estimates.

The worst performers, excluded from Figure 2, are the island economies, some of which export nothing to China, including Cape Verde and Comoros. Mauritius's industrial exports to China struggle to remain competitive against China's own industries (Zafar, 2007).

The density of 'under' trading among this typology is worrying because of the long-run implications for development. In particular, such a trade profile means these coastal, resource-scarce economies - with their relative "lack of agglomeration economies in labour-intensive manufactures" - require a combination of temporary protection from Asian competition in OECD markets and "ingenious" growth strategies if they are to become middle-income economies (Venables, 2008: 59; Collier, 2008, p. 8). Yet, there is every indication that these economies are not sufficiently supported by policies to facilitate the development of their trade capacity: no coastal economy plays host to a special economic zone; few coastal and resource-poor economies are LDCs, so few benefit from access to China's trade preferences for Africa. Economies of this typology are also the least likely to have recognised China as a market economy ahead of WTO requirements.

\section{5-3 Landlocked and Resource-poor}

Eleven of the 13 economies that Collier and O'Connell (2007) categorised as landlocked and resource-poor are LDCs. Lesotho and Zimbabwe are the exceptions, but they border South Africa and we lack data for them. According to our survey, only four of these nations had granted China market economy status by 2009. Among those countries, only Burkina Faso does not observe the One China Policy. On the basis that the success of China's own SEZs was related to their proximity to ports, it is surprising that one of the four African SEZs that China has fostered is in Ethiopia, a landlocked (and resource-poor) nation.

\section{INSERT FIGURE 3 ABOUT HERE:}

Excluding Congo DRC and the former Sudan, as illustrated in Figure 3, all countries in this group are 'under' exporting to China. Congo DRC in contrast exports more than seven times the predicted level and former Sudan thirty times the predicted level. The definition of resource-rich used by Collier and O'Connell (2007) was 
derived from their sample period (1960-2000). Thanks to China some newer larger-scale resource-exporters, including former Sudan, may not now be appropriately classified.

Ethiopia's exports to China have made the most relative progress against predicted levels over the sampled period - rising from less than 1 percent of predicted levels in 1995 to becoming a marginal 'over-exporter' for the first time in 2009. All other countries are under-exporting, with some barely reaching a few percentage points of the predicted levels. Malawi's trading relations with China has increased relatively rapidly from 2007, a trend that may relate to it ending its long-standing recognition of Taipei in that year. Niger's low export levels are not matched by a low import dependency. Rather, among economies south of the Sahara, Niger's import dependency with China is among the highest (see Table 3). Burundi is the worst export performer against predicted levels, realising less than 1 percent of predicted exports in 2009.

\section{Conclusion}

For decades, the diverse economies of SSA have played a peripheral role in international trade, with the exception of a few oil exporters and South Africa. While aggregate China-Africa trade relations continue to be dominated by oil, increased trade in general and the absence of colonial legacy issues point to a paradigm shift in economic opportunity for the region. There is the potential for China, as a large-scale and major emerging power, to better promote the global economic integration of Africa south of the Sahara in a way comparable to the effects of Japanese and Western trade and investment on economic integration across Asia in second half of the twentieth century.

Despite evidence of a diminishing gap between actual and expected trade flows in most countries over our sample period, China's trade with sub-Saharan Africa nonetheless still largely follows the recognisable historical default of North-South type trade: the exchange of Chinese manufactures for African commodities. This has heighted fears that such trade will diminish non-mineral and non-agricultural development opportunities for African economies. Despite China offering trade preferences to African LDCs and setting up five sub-Saharan investment zones, there is the risk that coastal economies especially will not be able to attain a critical manufacturing threshold in the face of competition from China. China's promise to increase its imports from African economies and to optimise the 
structure of trade may come to naught in the absence of other policies to promote development.

Our modelling produced results typical of gravity model for GDP and distance variables. We uniquely accounted for the role of island economies in China's trade pattern. We found that steps to reduce policy distance as proxied by recognition of market economy status was, as predicted, associated with increased imports. Steps to increase general policy distance through non-recognition of the One China policy - that is, recognizing Taipei instead of Beijing - were not statistically significantly associated with diminished export flows to China. This may reflect sampling bias, since relatively few countries recognise Taipei and those that do are very small economies, which could bias our results.

Our results estimated the gap between predicted and actual exports to China from Africa, roughly quantifying the gravity of China's trade promise. It was found, as hypothesised, that China commonly 'over'-imported with resource-rich countries, but far from uniformly so. Liberia, Sierra Leone and Guinea stand out as 'under' exporters among resource-rich countries, alongside Cameroon. On the other hand, our results find that China near universally 'under'-imported from resource-poor countries, both coastal and landlocked, and especially from island economies. An exception is Mozambique, which lies on the Indian Ocean - thus closer to China than many African countries - and whose trade with China in recent years has expanded dramatically.

China's support for so far five SEZs in sub-Saharan Africa, in Ethiopia, Mauritius, Nigeria (two) and Zambia is intended as a positive step in the direction of more advanced exports and related investment. To date, the location of the zones has by-passed the needs and potential of Africa's China-under exporting coastal and resource poor economies. Most the countries of this typology also do not qualify for China's LDC trade preferences. And yet these are largely the economies closest to the industrial and coastal agglomeration frontier, such Ghana and Kenya. It is arguably also these economy types that more closely resemble the trade potential of China's Guangdong and Fujian, which each hosted what went on to become booming foreign-invested trade zones.

At this stage trade comprises the major element of exchange between China and African economies. China remains a developing economy, but its vastly greater scale and level of development positions it to assist African economies with 
relatively favourable and relevant economic assistance. This could ultimately best serve Chinese investor returns too.

Having scoped the potential size of China's promise to increase exports from Africa using gravity modelling, onward exploration of China and Africa trade ties might use general equilibrium modeling to explore bilateral trade from an African perspective, and also more deeply explore new policy. Policy studies that could better identify how China might best assist the coastal and resource-poor economies in Africa to improve their exports, especially manufactures, would be useful. The link between overseas Chinese workers and immigrants and trade flows, especially importation of China's manufactured goods might also shed useful insights. 


\section{References}

Akamatsu, Kaname (1961), 'A Theory of Unbalanced Growth in the World Economy'. Weltwirtschaftliches Archiv, 86, 196-217.

Akamatsu, Kaname (1962), 'A Historical Pattern of Economic Growth in Developing Countries.' The Developing Economies, Preliminary Issue No.1, 3-25.

Alden, C. (2007), China in Africa (London: Zed Books).

AllAfrica.com (09/12/12), 'Mozambique-China Trade Continues to Grow', accessed 11/12/12. http://allafrica.com/stories/201212090143.html

Anderson, J. (1979), A Theoretical Foundation for the Gravity Equation, The American Economic Review 69, 1, 106-116.

Anderson, J. and van Wincoop, E. (2003), 'Gravity with gravitas: A solution to the border puzzle', American Economic Review, 93, 1, 170-192.

Arbache, J. and J. Page (2007a), Patterns of Long Term Growth in Sub-Saharan Region (Washington, DC: World Bank).

Arora, V. and A. Vamvakidis (2010), 'China's Economic Growth: International Spillovers', IMF Working Paper 10/165.

Baldwin, R. and D. Taglioni (2006), 'Gravity for Dummies and Dummies for Gravity Equations', NBER Working Paper 12516.

Batra, A. (2004), 'India's global trade potential: the gravity model approach', ICRIER Working Paper 151.

Bénassy-Quéré, A. and Amina Lahrèche-Revil (2003), 'Trade Linkages and Exchange Rates in Asia: The Role of China', Working Paper 21, Centre d'Etudes Prospectives et d'Informations Internationales (CEPII).

Bergstrand, J. H. (1985), 'The Gravity Equation in International Trade: Some Microeconomic Foundations and Empirical Evidence', Review of Economics and Statistics, 67, 3, 474-81.

Bergstrand, J. (1989), 'The Generalized Gravity Equation, Monopolistic Competition, and the Factor-Proportions Theory in International Trade', The Review of Economics and Statistics, 71, 1, 143-153.

Borgatti, L. (2007), 'Pacific Islands Bilateral Trade, The role of Remoteness and of Transport Costs', United Nations World Institute of Development Economics Research, Research Paper 2007/21.

Bova, E. (2008), 'Exchange Rate Management for Commodity Booms: Examining Zambia's Copper Exports', Development Viewpoint 19, Centre for Development Policy and Research, School of African and Oriental Studies

Bussière, M. and B. Schnatz (2009). 'Evaluating China's Integration in World Trade with a Gravity Model Based Benchmark', Open Economies Review, 20,1, 85-111.

Brautigam, D., T. Farole, and X. Tang (2010), 'China's Investment in African Special Economic Zones: Prospects, Challenges, and Opportunities', Economic 
Premise, March, Number 5, World Bank Poverty Reduction and Economic Management Network.

Brautigam, D. and X. Tang (2011), 'African Shenzhen: China's Special Economic Zones in Africa', Journal of Modern African Studies, 49, 1, 27-54.

Broadman, H. (2007), Africa's Silk Road: China and India's New Economic Frontier (Washington, DC: World Bank).

Business Day (2011) 'Zuma seeks 'fair deal' in Africa's ties with China', http://www.businessday.co.za/articles/Content.aspx?id=141715, accessed 05/05/11.

Chen, M-X, A. Goldstein, N. Pinaud and H. Reisen (2006), 'China \& India: What's in it for Africa?', OECD Development Centre Policy Insights, 19. Paris, OECD.

Centre d'Etudes Prospectives et d'Informations Internationales (CEPII) Gravity Dataset (2010). Data retrieved in January 2011, from CEPII Gravity Dataset online.

Collier, P. and S. O'Connell (2007). 'Opportunities and Choices' in Ndulu, B., et al. (eds), Political Economy of Economic Growth in Africa, 1960-2000 (Cambridge: Cambridge University Press).

Collier, P. (2008), 'Growth Strategies for Africa', Growth Commission Working Paper No. 9. Washington, DC, World Bank.

Danchie, S. (2010), 'Towards More Balanced Trade within the Framework of the Forum for China-Africa Cooperation: The Impact of China on Africa's Trade', African Center for Economic Transformation.

Deardorff, A. (1998), 'Determinants of Bilateral Trade: Does Gravity Work in a Neoclassical World?', in The Regionalizational of the World Economy, University of Chicago Press.

Easterly, W. and R. Levine (1997), 'Africa's Growth Tragedy: Policies and Ethnic Divisions', Quarterly Journal of Economics, 112, 4, 1203-1250.

Economist, The (2011), 'Africa's Impressive Growth', http://www.economist.com/blogs/dailychart/2011/01/daily_chart, 06/01/12, accessed 02/2011.

Edmonds, C., S. La Croix, Y. Li (2008), 'China's Trade: Busting Gravity's bounds', Journal of East Asian Economics, 19, 455-466.

Eeden, J. van (2009), 'South African Quotas on Chinese Clothing and Textiles, Economic Evidence', Econex Research Note 9 (March 2009).

Eichengreen, B., Y. Rhee and H. Tong (2007), 'China and the Exports of Other Countries', Review of World Economics, 143, 2, 201-226.

Forum on China and Africa (FOCAC) homepage, www.focac.org, accessed March 2011.

Foster, V., W. Butterfield, C. Chen and N. Pushak (2009) Building Bridges: China's Growing Role as Infrastructure Financier for Sub-Saharan Africa (Washington, DC: World Bank). 
Giovannetti, G. and M. Sanfilippo (2009), 'Do Chinese exports crowd-out African goods? An econometric analysis by country and sector', European Journal of Development Research, 21, 4, 506-30.

Green, Stephen (2004), 'China's quest for market economy', China Brief, 4,16, Jamestown Foundation.

Greenaway, D., A. Mahabir and C. Milner (2008), 'Has China displaced other Asian countries exports?' China Economic Review. 19, 152-169.

Growth Commission, The (2008), The Growth Report: Strategies for Sustained Growth and Inclusive Development, Commission on Growth and Development (Washington, DC: The World Bank).

Helpman, E. E. and P. R. Krugman (1985), Market Structure and Foreign Trade (Cambridge, MA: MIT Press).

Hurd, M. (1979), 'Estimation in Truncated Samples when there is Heteroskedasticity', Journal of Econometrics, 11, 247-58.

International Monetary Fund (2010), International Financial Statistics, 2010. Data retrieved January 2011, from International Financial Statistics Online.

International Monetary Fund, Direction of Trade Statistics, 2010. Data retrieved January 2011, from Direction of Trade Statistics Online.

Jenkins, R. and C. Edwards (2006), 'The Effect of China and India's Growth and Trade Liberalization on Poverty in Africa', Department for International Development, DCP 70, London.

Kaplinsky, R. (2005), Globalization, Poverty and Inequality (Cambridge: Polity Press).

Kaplinsky, R. and M. Morris (2007), 'Do the Asian Drivers Undermine ExportOriented Industrialization in SSA?' World Development 36, 2, 254-273.

Martin, W., \& Herath, G. (2008). Estimating the Gravity Model When Zero Trade Flows Are Frequant. School of Accounting, Economics and Finance, Deakin University.

Minson, A. (2008). 'China's preferential trade policy for Africa', China-Africa Policy Brief, No 1, South Africa Institute for International Affairs.

Nambian, The (2007), The Chinese Charm Offensive.

http://www.namibian.com.na/index.php?id=28\&tx_ttnews[tt_news]=33660\&no_c ache $=1$. Accessed 05/02/07.

Panitchpakdi, S. and M. Clifford (2002), China and the WTO: Changing China, Changing World Trade, (Singapore John Wiley and Sons, Asia).

Pöyhönen, P. (1963), 'A Tentative Model for the Volume of Trade Between Countries,' Weltwirtschaftli-ches Archiv 90, 93-99.

PRC, State Council (2010). China-Africa Economic and Trade Cooperation. White Paper, issued by the Information Office of the State Council, People's Republic of China, December. http://news.xinhuanet.com/english2010/china/2010-

12/23/c_13661470.htm 
Radelet, S. (2010), Emerging Africa: How 17 countries are leading the way. (Washington, DC: Center for Global Development).

Rose, A. K. (2004), 'Do We Really Know That the WTO Increases Trade?', The American Economic Review, 94, 1, 98-114.

Silva, J. S. and S. Tenreyro (2005), 'The Log of Gravity', Centre for Economic Performance, Discussion Paper No. 701. London School of Economics.

Silva, J. S., \& Tenreyro, S. (2006). The log of gravity. The Review of Economics and statistics, 88(4), 641-658.

Shafaeddin, S. M. (2004), "Is China's accession to the WTO threatening exports of developing countries", China Economic Review, 15, 109-144.

Standard Bank (2011), 'China and the US in Africa: Measuring Washington's Response to Beijing's Commercial Advance', Economic Strategy, BRIC and Africa.

Stevens, C. and J. Kennan (2005), 'Opening the Package: the Asian Drivers and Poor-Country Trade', Institute of Development Studies (IDS), University of Sussex, 2-56.

Tinbergen, J. (1962), Shaping the World Economy; Suggestions for an International Economic Policy (New York, Twentieth Century Fund).

Venables, A. (2008), 'Re-thinking Growth in a Globalizing World: An Economic Geography Lens', Growth Commission Working Paper No. 18. World Bank.

Wang, Jianye, 2007, 'What Drives China's Growing Role in Africa?', IMF Working Paper 07/211, International Monetary Fund, Washington, DC

World Bank (2010). World Development Indicators. Data retrieved January 2011, from World Development Indicators Online.

World Trade Organization (2008), World Trade Report 2008, Geneva.

Zafar, A. (2007) 'The Growing Relationship Between China and Sub-Saharan Africa: Macroeconomic, Trade, Investment, and Aid Links'. World Bank Research Observer, 22, 1, 103-130. 
TABLE 1: Geographic Opportunity Typologies, Sub-Saharan Africa

\begin{tabular}{ll}
\hline Resource rich & $\begin{array}{l}\text { Nigeria, Cameroon, Angola, Zambia, Guinea, Sierra Leone, Congo } \\
\text { (Republic), Liberia, Mauritania, Namibia, Botswana, Gabon, }\end{array}$ \\
& Swaziland, Equatorial Guinea \\
Resource-poor and & South Africa, Tanzania, Kenya, Ghana, Mozambique, Madagascar, \\
Coastal & Cote d'Ivoire, Senegal, Benin, Somalia, Togo, Eritrea, Gambia, \\
& The, Guinea-Bissau, Mauritius, Comoros, Cape Verde, Djibouti, Sao \\
& Tome and Principe, Seychelles \\
Resource-poor and & Ethiopia, Congo (Democratic Republic), Sudan, Uganda, Burkina \\
Landlocked & Faso, Niger, Malawi, Zimbabwe, Mali, Chad, Rwanda, Burundi, \\
& Central African Republic ,Lesotho \\
\hline
\end{tabular}

Source: Growth Report (2008: 75).

TABLE 2: Trade impacts of Asian drivers on economies in Africa

\begin{tabular}{lll}
\hline & \multicolumn{1}{c}{ Direct } & \multicolumn{1}{c}{ Indirect } \\
\hline Complementary & Growth of export markets & $\begin{array}{l}\text { Positive terms of trade } \\
\text { Shifts }\end{array}$ \\
Competitive & $\begin{array}{l}\text { Displacement of local } \\
\text { production }\end{array}$ & $\begin{array}{l}\text { Competition in } \\
\text { third export markets }\end{array}$ \\
\hline
\end{tabular}

Source: Jenkins and Edwards (2005, p. 6)

TABLE 3: China-Africa Trade Dependencies (\% of Total, 2009)

\begin{tabular}{lclc}
\hline Exports & $\%$ & Imports & $\%$ \\
\hline Sudan & 58.0 & Togo & 36.58 \\
DemCongo & 46.8 & Benin & 35.62 \\
Mauritania & 41.1 & Sudan & 21.87 \\
Angola & 35.6 & Gambia & 20.45 \\
Congo Rep. & 30.2 & Equatorial Guinea & 19.97 \\
Zambia & 21.4 & Angola & 17.37 \\
Gabon & 16.0 & Niger & 16.32 \\
Mali & 13.2 & Nigeria & 14.89 \\
Benin & 12.7 & Comoros & 14.66 \\
Equatorial Guinea & 12.6 & Congo Rep. & 14.54 \\
\hline
\end{tabular}

Source: Author's own calculations, IMF, International Trade Statistics

Note: Export dependency is the ratio of bilateral exports to one country to total exports; import dependency is calculated similarly. 
TABLE 4: Composition of China's imports and exports, world and Africa, 2009, \$bn

\begin{tabular}{|c|c|c|c|c|}
\hline & \multicolumn{2}{|c|}{ Exports } & \multicolumn{2}{|c|}{ Imports } \\
\hline & World & Africa & World & Africa \\
\hline Agricultural products & $\begin{array}{l}40.88 \\
(3.40 \%)\end{array}$ & $\begin{array}{r}1.59 \\
(3.43 \%)\end{array}$ & $\begin{array}{r}76.62 \\
(7.62 \%)\end{array}$ & $\begin{array}{r}2.09 \\
(4.82 \%)\end{array}$ \\
\hline Food & 35.32 & 1.48 & 45.25 & 0.63 \\
\hline Raw materials & 5.56 & 0.11 & 31.37 & 1.46 \\
\hline Fuels and mining products & $\begin{array}{r}34.33 \\
(2.86 \%)\end{array}$ & $\begin{array}{r}0.85 \\
(1.83 \%)\end{array}$ & $\begin{array}{r}250.46 \\
(24.91 \%)\end{array}$ & $\begin{array}{r}37.73 \\
(87.08 \%)\end{array}$ \\
\hline Ores and other minerals & 1.86 & 0.04 & 88.77 & 6.36 \\
\hline Fuels & 20.38 & 0.31 & 123.96 & 27.89 \\
\hline Non-ferrous metals & 12.09 & 0.51 & 37.72 & 3.48 \\
\hline Manufactures & $\begin{array}{r}1,124.74 \\
(93.60 \%)\end{array}$ & $\begin{array}{r}43.86 \\
(94.67 \%)\end{array}$ & $\begin{array}{r}675.1 \\
(67.14 \%\end{array}$ & $\begin{array}{r}2.61 \\
(6.02 \%)\end{array}$ \\
\hline Iron and steel & 23.66 & 2.38 & 26.48 & 1.04 \\
\hline Chemicals & 62.01 & 2.69 & 111.97 & 0.55 \\
\hline Other semi-manufactures & 89.2 & 6.08 & 28.59 & 0.66 \\
\hline $\begin{array}{l}\text { Machinery and transport } \\
\text { equipment }\end{array}$ & 591.13 & 18.29 & 408.26 & 0.26 \\
\hline Office and telecom equipment & 346.45 & 4.87 & 214.05 & 0.2 \\
\hline Transport equipment & 64.75 & 4.42 & 51.97 & 0.01 \\
\hline Textiles & 59.82 & 5.68 & 14.94 & 0.01 \\
\hline Clothing & 107.26 & 3.09 & 1.84 & 0.06 \\
\hline Other manufactures & 191.66 & 5.65 & 83.09 & 0.03 \\
\hline Total merchandise & $1,201.65$ & 46.33 & $1,005.56$ & 43.33 \\
\hline
\end{tabular}

Source: WTO, International Trade Statistics 2010 (values in brackets reflect \% of total). 
TABLE 5: OLS and PPML benchmark results

\begin{tabular}{|c|c|c|c|c|}
\hline Chinam & OLS Base (1) & PPML Base (1) & OLS Aug. $(1+Z)$ & PPML Aug. $(1+Z)$ \\
\hline \multirow[t]{2}{*}{ Constant } & $60.101 * * *$ & $16.262^{*}$ & $54.723 * * *$ & $22.247 * *$ \\
\hline & $(4.996)$ & $(8.584)$ & $(5.005)$ & $(10.057)$ \\
\hline \multirow[t]{2}{*}{ InGDPlag1 } & $1.126 * * *$ & $0.481 * * *$ & $1.136 * * *$ & $0.478 * * *$ \\
\hline & $(0.103)$ & $(0.037)$ & $(0.101)$ & $(0.043)$ \\
\hline \multirow[t]{2}{*}{ IncGDPlag1 } & $-0.863^{*}$ & $-1.631 *$ & $-0.877 * *$ & $-2.283 * *$ \\
\hline & $(0.455)$ & $(0.894)$ & $(0.441)$ & $(1.058)$ \\
\hline \multirow[t]{2}{*}{ Inexc } & $-0.552 *$ & -0.006 & -0.353 & $0.109 * *$ \\
\hline & $(0.302)$ & $(0.065)$ & $(0.293)$ & $(0.055)$ \\
\hline \multirow[t]{2}{*}{ Indistance } & $-5.854 * * *$ & $-0.846 * * *$ & $-5.314 * * *$ & $-0.705^{* * *}$ \\
\hline & $(0.401)$ & $(0.048)$ & $(0.414)$ & $(0.042)$ \\
\hline \multirow[t]{2}{*}{ Inpop } & $0.639 * * *$ & $0.243 * * *$ & $0.736 * * *$ & $0.358 * * *$ \\
\hline & $(0.141)$ & $(0.053)$ & $(0.137)$ & $(0.051)$ \\
\hline \multirow[t]{2}{*}{ Incpop } & - & $15.941 * * *$ & - & $10.750 *$ \\
\hline & & $(5.588)$ & & $(5.628)$ \\
\hline \multirow[t]{2}{*}{ Landlk } & -0.528 & $-0.868 * * *$ & 0.510 & $-0.571 * * *$ \\
\hline & $(0.483)$ & $(0.165)$ & $(0.472)$ & $(0.152)$ \\
\hline \multirow[t]{2}{*}{ Islandsall } & $5.309 * * *$ & $0.466 * * *$ & $4.817 * * *$ & $0.408 * * *$ \\
\hline & $(0.513)$ & $(0.098)$ & $(0.500)$ & $(0.078)$ \\
\hline \multirow[t]{2}{*}{ Contig } & $-5.855 * * *$ & $0.752 * * *$ & $-4.872 * * *$ & $-1.014 * * *$ \\
\hline & $(0.831)^{* * *}$ & $(0.179)$ & $(0.822)$ & $(0.180)$ \\
\hline \multirow[t]{2}{*}{ Huaqiao } & & & $14.539 * * *$ & $1.642 * * *$ \\
\hline & & & $(1.580)$ & $(0.203)$ \\
\hline \multirow[t]{2}{*}{ Onechina } & & & $3.501 * * *$ & $-0.706 * *$ \\
\hline & & & $(0.539)$ & $(0.346)$ \\
\hline \multirow[t]{2}{*}{ Market } & & & 0.265 & $0.359 * * *$ \\
\hline & & & $(0.547)$ & $(0.107)$ \\
\hline $\mathrm{R}^{2}$ & 0.2982 & 0.734 & 0.3419 & 0.651 \\
\hline Observations & 2409 & 2409 & 2409 & 2409 \\
\hline
\end{tabular}


TABLE 6: Augmented Model; Time Period Effects (PPML)

\begin{tabular}{|c|c|c|c|}
\hline Chinam & Full sample (5) & t1 (6) & t2 (7) \\
\hline \multirow[t]{2}{*}{ Constant } & $22.780 * *$ & 4.512 & -5.987 \\
\hline & $(10.010)$ & $(8.326)$ & (7.187) \\
\hline \multirow[t]{2}{*}{ InGDPlag1 } & $0.462 * * *$ & $0.434 * * *$ & $0.510 * * *$ \\
\hline & $(0.046)$ & $(0.055)$ & $(0.059)$ \\
\hline \multirow[t]{2}{*}{ IncGDPlag1 } & $-2.207 * *$ & 0.034 & $-1.008 * *$ \\
\hline & $(1.053)$ & $(0.727)$ & $(0.474)$ \\
\hline \multirow[t]{2}{*}{ Inexc } & $0.143 * *$ & $0.290 * * *$ & 0.130 \\
\hline & $(0.069)$ & $(0.087)$ & $(0.081)$ \\
\hline \multirow[t]{2}{*}{ Indistance } & $-0.818 * * *$ & $-0.886 * * *$ & $-0.799 * * *$ \\
\hline & $(0.043)$ & $(0.062)$ & $(0.050)$ \\
\hline \multirow[t]{2}{*}{ Inpop } & $0.401 * * *$ & $0.497 * * *$ & $0.319 * * *$ \\
\hline & $(0.056)$ & $(0.087)$ & $(0.067)$ \\
\hline \multirow[t]{2}{*}{ Incpop } & $10.569 *$ & 11.115 & $75.583 * *$ \\
\hline & $(5.588)$ & (13.567) & (30.175) \\
\hline \multirow[t]{2}{*}{ Landlk } & $-0.613 * * *$ & $-1.042 * * *$ & $-0.459 * * *$ \\
\hline & $(0.151)$ & $(0.293)$ & $(0.143)$ \\
\hline \multirow[t]{2}{*}{ Island } & $-0.516 * * *$ & $-0.904 * * *$ & $-0.367 * *$ \\
\hline & $(0.146)$ & $(0.259)$ & $(0.154)$ \\
\hline \multirow[t]{2}{*}{ Contig } & $-1.207 * * *$ & $-1.197 * * *$ & $-1.038 * * *$ \\
\hline & $(0.198)$ & $(0.337)$ & $(0.218)$ \\
\hline \multirow[t]{2}{*}{ Huaqiao } & $1.565 * * *$ & $1.705^{* * *}$ & $1.329 * * *$ \\
\hline & $(0.197)$ & $(0.533)$ & $(0.236)$ \\
\hline \multirow[t]{2}{*}{ Onechina } & -0.422 & 0.046 & -0.359 \\
\hline & $(0.327)$ & $(0.558)$ & $(0.409)$ \\
\hline \multirow[t]{2}{*}{ Market } & $0.349 * * *$ & - & $0.381 * * *$ \\
\hline & $(0.001)$ & & $(0.125)$ \\
\hline $\mathrm{R}^{2}$ & 0.642 & 0.865 & 0.607 \\
\hline Observations & 2409 & 1345 & 1367 \\
\hline
\end{tabular}

Table 7: Over and Under-trading averages by typology group*

\begin{tabular}{lcr}
\hline Typology & 1995 & 2009 \\
\hline Resource-Rich & 0.152 & 13.050 \\
Excluding Angola & 0.126 & 4.813 \\
Resource-Poor \& Landlocked & 0.029 & 3.435 \\
Excluding former Sudan \& Congo DRC & 0.012 & 0.360 \\
Resource-Poor \& Coastal & 0.212 & 3.405 \\
Excluding South Africa & 0.010 & 0.337 \\
\hline Overall & 0.141 & 6.066 \\
\hline Where <1=under-trading; 1=trading as predicted; >1 over-trading.
\end{tabular}

Where $<1=$ under-trading; $1=$ trading as predicted; $>1$ over-trading. 
FIGURE 1: Over/Under Export of Coastal and Resource-Poor Countries

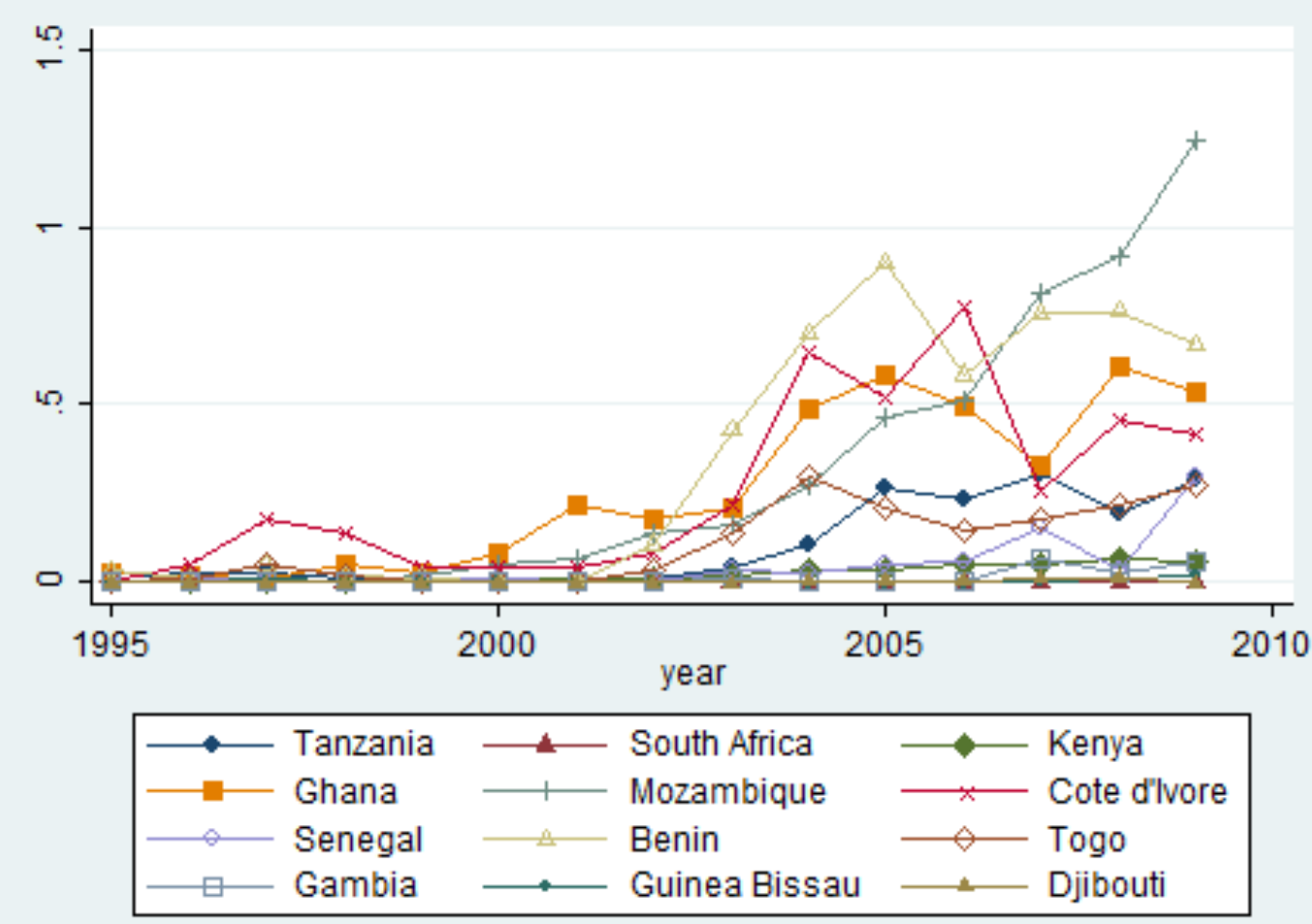

FIGURE 2: Over/Under Exporter by Resource-Rich Economies to China

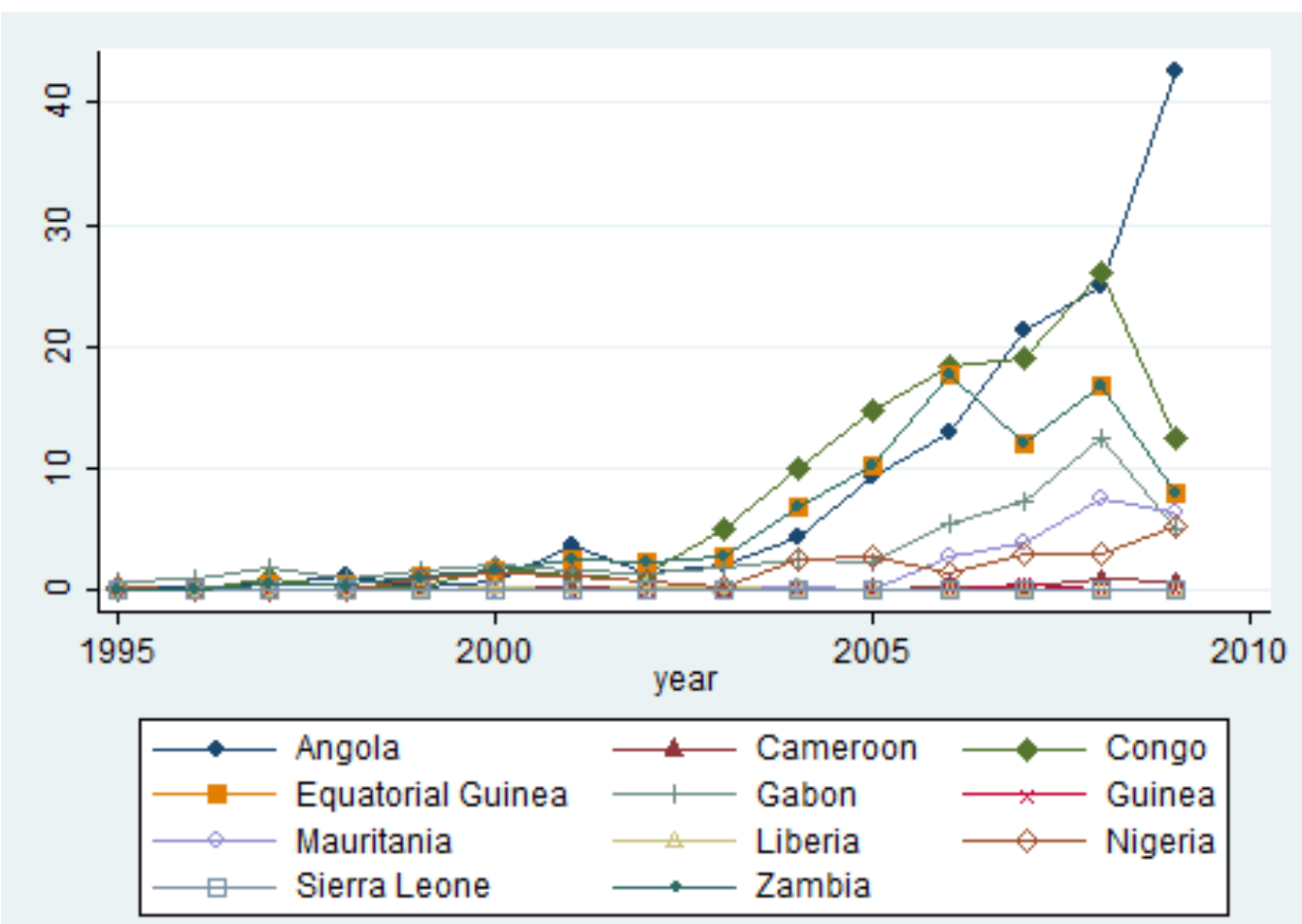


Figure 3: Over/Under-Trading: Resource-Poor and Landlocked countries

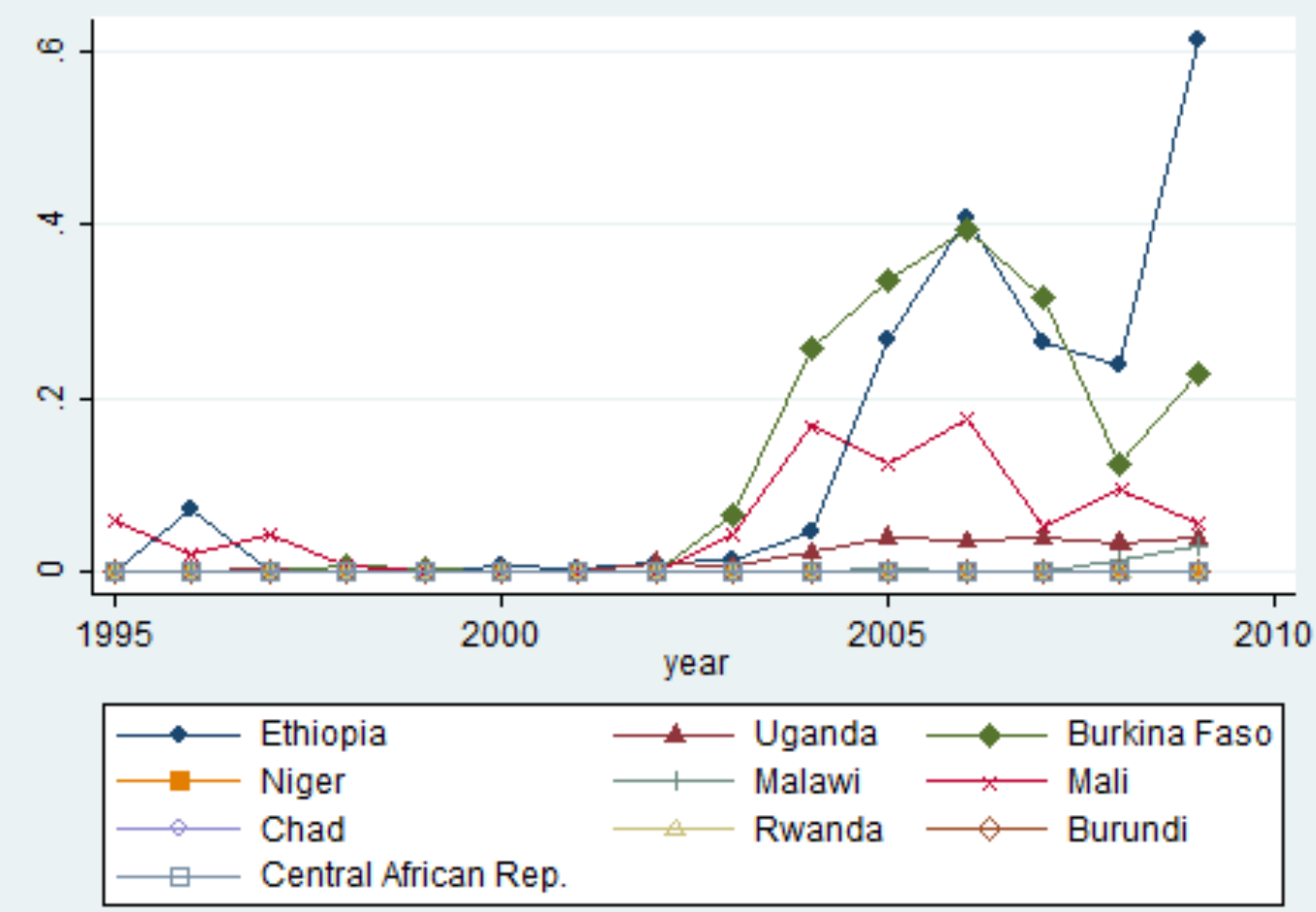

